\title{
A Case of Syringomatous Adenoma of the Nipple
}

\author{
Yuko Ichinokawa $^{\mathrm{a}}$ Akiko Ohtuki $^{\mathrm{a}}$ Mariko Hattori $^{\mathrm{a}}$ \\ Hiroko Sadamasa ${ }^{a}$ Masataro Hiruma ${ }^{a}$ \\ Toshiharu Matumoto ${ }^{b}$ \\ Departments of ${ }^{\mathrm{a}}$ Dermatology and Allergology and ${ }^{\mathrm{b}}$ Diagnostic Pathology, \\ Juntendo University Nerima Hospital, Tokyo, Japan
}

\section{Key Words}

Syringomatous adenoma of the nipple $\cdot$ Nodule $\cdot$ Areola $\cdot$ Eccrine sweat ducts

\begin{abstract}
Syringomatous adenoma of the nipple (SAN) is an extremely rare disease originating in the adnexal gland; it was first reported by Rosen in 1983 [Am J Surg Pathol 1983;7:739-745]. Since then, 34 cases have been reported worldwide. We present the case of a 51-year-old man with SAN, in whom local excision of the tumor was performed. Histologically, the tumor consisted of tubules, ductules and epithelial cell strands, and most of the proliferating ducts presented with a characteristic teardrop or comma-shaped appearance.
\end{abstract}

\section{Introduction}

In 1983, Rosen [1] first described syringomatous adenoma of the nipple (SAN), a benign tumor of the breast that shows locally infiltrative proliferation and is histologically similar to syringomas. Since then, 34 cases have been reported worldwide. We describe a case of SAN that is the fourth in Japan and the first case reported here within the field of dermatology.

\section{Case Report}

The patient was a 51-year-old male office worker who visited the Dermatology and Allergology Clinic of our hospital in July 2009 for evaluation of a subcutaneous nodule in the right breast. He had first noticed the lump 5 years earlier and had become concerned as the lump gradually increased in size. Both personal and family medical history were unremarkable.

The lesion was a relatively well-circumscribed, elastic, hard, 17-mm subcutaneous nodule adjacent to the areola of the right breast. The lesion was covered by normal-colored skin and protruded 
slightly (fig, 1). We considered the lesion likely to be a mammary gland tumor, and the patient was referred to the Department of Breast Surgery for further evaluation.

Mammography showed a well-circumscribed nodule with a smooth margin on the outside of the upper right breast. Ultrasonography showed a well-circumscribed hypoechoic area on the same site. Standard laboratory tests were normal. These results indicated that the lesion was not a malignant tumor; furthermore, it was determined that the lesion had not derived from the mammary gland.

Total excision of the lesion was performed at the Department of Dermatology and Allergology. Histopathological analysis revealed several relatively well-circumscribed nodular lesions occurring from within the dermis to the subcutaneous tissue. Cells within the nodules showed two phases: (i) proliferating tumor cells with compressed duct-like structures surrounded by fibrotic stromal cells and (ii) other scattered tumor cells filled with abundant mucus and with no apparent duct-like structures. Transition between the two phases was observed (fig. 2a). The highly magnified image of the duct-like structures showed proliferation of multilayered epithelial cell nests forming commashaped partial ducts. The duct-like structures were composed of an external layer of relatively palestained tumor cells and an internal layer of tumor cells with eosinophilic cytoplasm (fig. 2b). The stromal cells tested positive for Alcian blue staining and showed deposition of mucus and hyalinization of collagen fibers. Images of dyskaryosis or karyokinesis in the tumor cells were unremarkable.

In immunohistochemical staining, the cells within the lesions all tested positive for antibodies to AE1/AE3, CK7, CAM5.2, p63, SMA and s-100 protein. The myoepithelial cells were positive for antip63 antibody, and the epithelial cells were negative; thus, the epithelial cell nests showed a biphasic staining pattern, confirming their benign nature. The cells within the lesions were negative for antibodies to estrogen and progesterone receptors. Based on the morphological features and the findings of the immunohistochemical staining, these tumors were diagnosed as SAN.

\section{Discussion}

There have been English-language reports on 34 cases of SAN since Rosen [1] initially reported 5 cases in 1983 (table 1). SAN is a locally infiltrative tumor that does not cause distant metastasis; however, recurrence has been reported in cases of incomplete excision [2-7].

SAN is a rare tumor, and diagnosis can be difficult. Based on histological classification of mammary gland tumors, differential diagnoses include nipple adenomas and low-grade adenosquamous carcinomas. Nipple adenomas are papillary or solid adenomas developing within the nipple where proliferation of papillary epithelium is remarkable [1,2]. Low-grade adenosquamous carcinomas that derive from the salivary gland duct show an adenoma-like structure. Because they frequently develop in the large and small salivary glands, these carcinomas can be differentiated from their sites of origin [8].

Based on histological classification of apocrine and eccrine sweat gland tumors, differential diagnoses include malignant mixed tumors and microcystic adnexal carcinomas (MACs) $[9,10]$. Malignant mixed tumors are composed of both epithelial and stromal components and have a cartilage-like appearance. MACs derive from the eccrine sweat ducts and have an upper layer composed of funicular, keratinous cystlike and syringoma-like structures, and a lower layer composed of duct-like structures and funicular structures. The face is a common anatomic site for MACs. MACs differ from SAN in that they have a high recurrence rate, compared to a low recurrence rate for SAN even after conservative excision. Another difference is that metastasis of MACs has been reported, but there have been no reports of SAN metastasis [11]. 
SAN forms comma-shaped cell nests or small glandular cavities with single or multiple layers of small homogeneous epithelial cells in a background of dense stromal cells. It proliferates and can infiltrate tissue from the nipple to as far as the subareolar stroma. Some SAN differentiate to squamous epithelium.

Based on morphological features, we diagnosed the tumors in this case as SAN. The tumors are likely to have originated from the eccrine sweat ducts remaining in the breast. To our knowledge, only 4 cases of SAN, including our case, have been reported in Japan since 1983. The cases include 3 women and 1 man, ranging in age from 36 to 87 years (mean age 63). The sites of origin were the nipple in 3 cases and the areola in 1 case.

Various tumors develop in the breast. Dermatologists do not typically encounter this rare tumor; thus, caution is required. SAN should also be considered as one of the differential diagnoses. Careful excision is necessary for the treatment of SAN in order to avoid recurrence of the tumor. 
Table 1. Cases of SAN

\begin{tabular}{|c|c|c|c|c|c|}
\hline $\begin{array}{l}\text { Patient } \\
\text { no. }\end{array}$ & $\begin{array}{l}\text { Age } \\
\text { years }\end{array}$ & Sex & $\begin{array}{l}\text { Size } \\
\mathrm{cm}\end{array}$ & Treatment & Recurrence \\
\hline 1 & 36 & $\mathrm{~F}$ & 3 & Biopsy & Yes \\
\hline 2 & 28 & $\mathrm{~F}$ & 2 & Local excision & No \\
\hline 3 & 38 & $\mathrm{~F}$ & 1.5 & Local excision & No \\
\hline 4 & 41 & $\mathrm{~F}$ & 1.2 & Simple mastectomy & No \\
\hline 5 & 76 & $\mathrm{M}$ & 1.1 & Complete excision & No \\
\hline 6 & 67 & $\mathrm{~F}$ & 1 & Local excision & Yes \\
\hline 7 & 40 & $\mathrm{~F}$ & 1.2 & Local excision & No \\
\hline 8 & 33 & $\mathrm{~F}$ & 1 & Local excision & Yes \\
\hline 9 & 23 & $\mathrm{~F}$ & 1 & Local excision & No \\
\hline 10 & 61 & $\mathrm{~F}$ & 2 & Local excision & No \\
\hline 11 & 61 & $\mathrm{~F}$ & 2 & Local excision & Yes \\
\hline 12 & 63 & $\mathrm{~F}$ & 2.2 & Subcutaneous mastectomy & Yes \\
\hline 13 & 11 & $\mathrm{~F}$ & 1.3 & Local excision & Yes \\
\hline 14 & 31 & $\mathrm{~F}$ & 1 & Local excision & No \\
\hline 15 & 28 & $\mathrm{~F}$ & 3 & Local excision & Unknown \\
\hline 16 & 22 & $\mathrm{~F}$ & 2 & Local excision & Unknown \\
\hline 17 & 66 & $\mathrm{~F}$ & 3.5 & Simple mastectomy & No \\
\hline 18 & 34 & $\mathrm{~F}$ & Not given & Local excision & No \\
\hline 19 & 74 & $\mathrm{~F}$ & 3 & Simple mastectomy & No \\
\hline 20 & 61 & $\mathrm{~F}$ & 2 (right), 1 (left) & R: simple mastectomy/L: local excision & No \\
\hline 21 & 35 & $\mathrm{~F}$ & 1 & Partial mastectomy & No \\
\hline 22 & 68 & $\mathrm{~F}$ & 1.5 & Mastectomy with axillary node sampling & No \\
\hline 23 & 71 & $\mathrm{~F}$ & 2 & Local excision & No \\
\hline 24 & 45 & $\mathrm{~F}$ & 2 & Local excision & No \\
\hline 25 & 41 & $\mathrm{~F}$ & Not given & Local excision & No \\
\hline 26 & 23 & $\mathrm{~F}$ & $3.5 \times 2.5 \times 1.6$ & Local excision & No \\
\hline 27 & 36 & $\mathrm{~F}$ & 2 & Local excision & No \\
\hline 28 & 87 & $\mathrm{~F}$ & 1 & Simple mastectomy & Unknown \\
\hline 29 & 76 & $\mathrm{~F}$ & 3 & Mastectomy with axillary lymphadenectomy & Unknown \\
\hline 30 & 44 & $\mathrm{~F}$ & 0.75 & Local excision & No \\
\hline 31 & 32 & $\mathrm{~F}$ & 0.5 & Local excision & No \\
\hline 32 & 39 & $\mathrm{~F}$ & Not given & Local excision & No \\
\hline 33 & 32 & $\mathrm{~F}$ & $4 \times 2$ & Local excision & No \\
\hline 34 & 40 & $\mathrm{~F}$ & 0.8 & Local excision & No \\
\hline
\end{tabular}




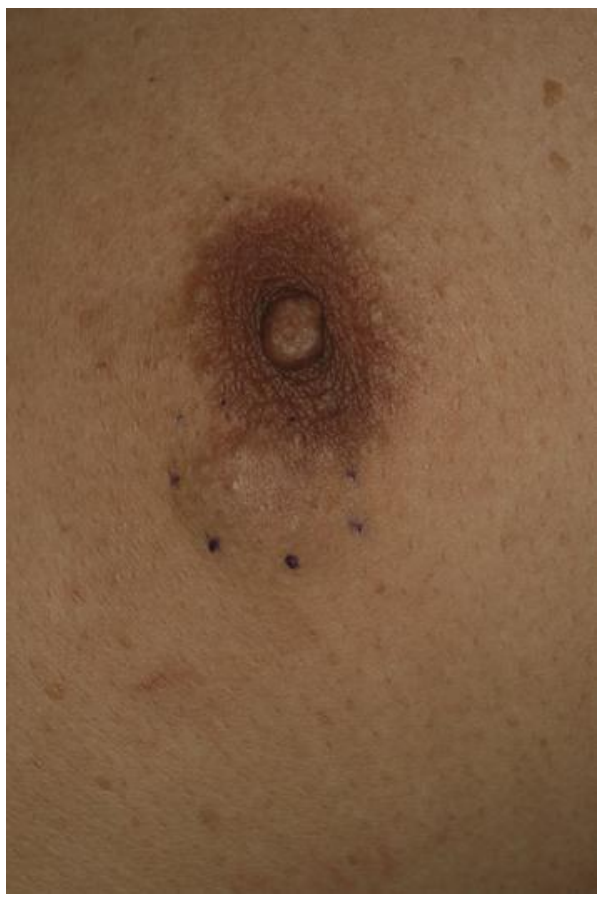

Fig. 1. A firm mass, $17 \mathrm{~mm}$ in diameter, located in the subareolar area, immediately to the right.
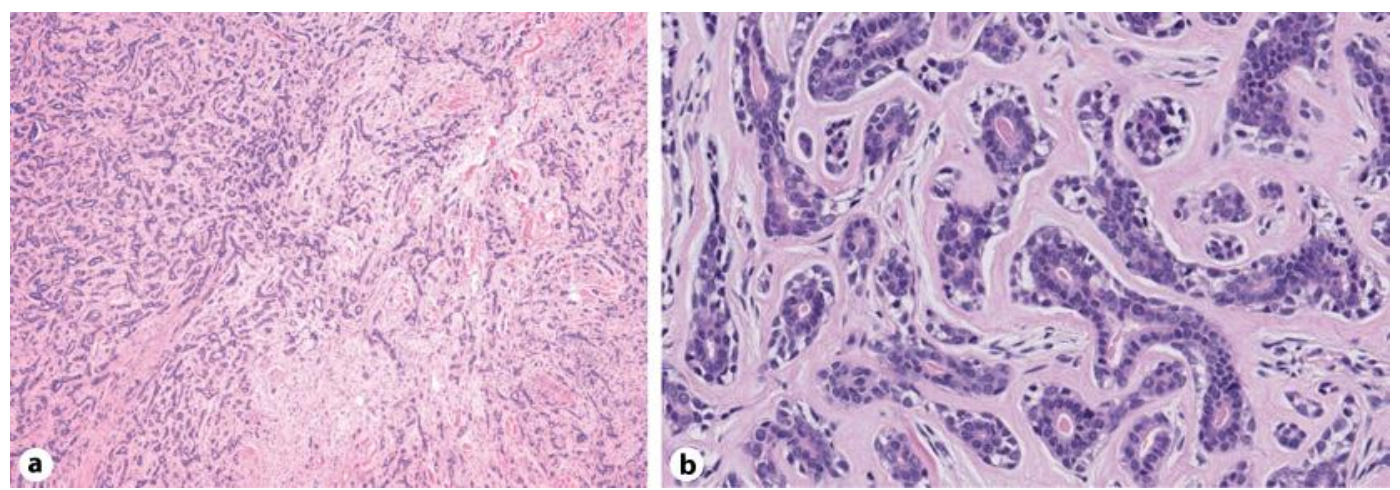

Fig. 2. a Compressed duct-like structures in a densely fibrotic stroma. $\mathbf{b}$ The ducts, lined by one or more layers of cells, have teardrop, comma-like and branching shapes, with lumens that are open and round or filled with small uniform cells. 


\section{References}

1 Rosen PP: Syringomatous adenoma of the nipple. Am J Surg Pathol 1983;7:739-745.

2 Carter E, Dyess DL: Infiltrating syringomatous adenoma of the nipple: a case report and 20-year retrospective review. Breast J 2004;10:443-447.

-3 Chang CK, Jacobs IA, Calilao G, Salti GI: Metastatic infiltrating syringomatous adenoma of the breast. Arch Pathol Lab Med 2003;127:e155-e156.

4 Wadhwa N, Mishra K, Agarwal S: Syringomatous adenoma of the nipple: a case report. Pathology 2003;35:271-272.

$5 \mathrm{Ku}$ J, Bennett RD, Chong KD, Bennett IC: Syringomatous adenoma of the nipple. Breast 2004;13:412-415

6 Kubo M, Tsuji H, Kunimoto T, Taguchi K: Syringomatous adenoma of the nipple: a case report. Breast Cancer 2004;11:214-216.

-7 Yosepovic A, Perelman M, Ayalon S, Papa M, Kopolovic J: Syringomatous adenoma of the nipple: a case report. Pathol Res Pract 2005;201:405-407.

8 Rosen PP: Syringomatous adenoma of the nipple; in Rosen PP (ed): Rosen's Breast Pathology, ed 2. Philadelphia, Lippincott Williams and Wilkins, 2001, pp 111-114.

9 Patterson JW, Wick MR: Microcystic adnexal carcinoma (sclerosing sweat duct carcinoma); in Silverberg SG, Sobin LH (eds): Atlas of Tumor Pathology. Non-Melanocytic Tumors of the Skin. Washington, DC, Armed Forces Institute of Pathology, 2006, pp 158-161.

10 Klein W, Chan E, Seykora JT: Microcystic adnexal carcinoma; in Elder DE (ed): Lever's Histopathology of the Skin, ed 9. Philadelphia, Lippincott Williams and Wilkins, 2005, pp 911-912.

11 Ohta M, Hiramoto M, Ohtsuka H: Metastatic microcystic adnexal carcinoma: an autopsy case. Dermatol Surg 2004;30:957. 